\title{
THE SOCIAL CONDITIONS OF REGIONALISM IN THE HUNGARIAN BALATON REGION
}

\section{A REGIONALIZMUS TÁRSADALMI FELTÉTELEI A BALATON TÉRSÉGÉBEN MAGYARORSZÁGON}

\author{
Gergely KABAI ${ }^{\mathrm{a}}$ \\ ${ }^{a}$ University of Pécs, Faculty of Humanities, Interdisciplinary Doctoral School, Program of Political \\ Science, e-mail: kabai.gergely@pannonelemzo.hu
}

Cite this article: Kabai, G. (2017). The Social Conditions of Regionalism in the Hungarian Balaton Region. Deturope, 9, 1: 111-129

\begin{abstract}
This paper shows the social conditions of Lake Balaton area. The first part presents the theoretical framework for the cohesion of society. The second part describes the processes that led to the complexity of local society in Lake Balaton area in the 20th century. Then, the paper presents the problems of cohesion about the society of Lake Balaton area. The author concludes that although there is a strong local cohesion in the society, but this phenomenon is geographically, dimensionally and thematically different in the area. All of this does not prevent the processes of bottom-up regionalization, which is a hundred years old phenomen in that area.
\end{abstract}

Keywords: Regionalism, cohesion of society, social capital, Lake Balaton, Hungary

\begin{abstract}
Absztrakt
A tanulmány a Balaton térségének társadalmi jellemzőit taglalja, a regionalizmus kialakulásának tekintetében.A társadalmi kohézió elméleti kereteinek áttekintését követően bemutatja azokat a folyamatokat, amelyek a balatoni társadalom összetettségét eredményezték. Ezt követően e kohézió dimenzióinak tárgyalása és problémáinak bemutatása következik. A szerző arra a következtetésre jut, hogy bár a helyi társadalmi kohézió sok tekintetben kimutatható, de az területileg, tartalmában és egyes társadalmi érdekcsoportok tekintetében is megosztott a Balaton térségén belül. A regionalizmus folyamatát ez nem gátolja; a meghatározóan erős területi kötődés ösztönzőleg hat.
\end{abstract}

Kulcsavak: Regionalizmus, társadalmi kohézió, társadalmi tőke, Balaton

\section{INTRODUCTION}

Following the Hungarian change of government in 2010 the topic of creating regions, thus the question of regionalization, was seemingly removed from the agenda of domestic territorial policy. An almost two decade long debate came to an end with the fact that the Hungarian regional middle level remained the county, following historical traditions. Nevertheless, the earlier functions of the county have been transformed: averting from the field of supporting 
institutions it obtained tasks in the mid-level administration and (from 2014) in the development policy system.

The role of regions has changed in European territorial policy as well. Beside the approach used for decades, which was thinking in large regions, following the aim at equalization with a certain universalism, in the last years the local scene, the communities and the emphasizing of bottom-up building gained ground as well. The study of OECD (2006) was a mile stone in this process which, instead of the earlier sectoral approaches, in line with the new rural country paradigm placed the location in the centre of attention and development. The Barca report, constructed in 2009, was of similar importance in the policy of the EU. The document defined cohesion policies as place-based policy by building on a completely new rationale. Instead of the administrative regions the location appeared as a territorial base unit. (Barca, 2009; Illés, 2009)

It might not seem practical to write a thesis on the question of regional self-governance with such policy phenomena nowadays. However, the area of Lake Balaton might be an exception, which has "defied" various eras of territorial policies in the past 100 years and the issue of self-government, territorial independence and self-organization appears again. The work of the Balaton Association in the first part of the 20th century (Marton, 2013) can be listed here; the declaration of the Balaton County in 1919 (Agg, 1991); as well as the rebirth of similar intentions from the 1990s (Oláh, 2007).

My study intents to show those social phenomena that provide the background and motivation for those political processes that can be described with the concept of regional selfgovernance or regionalism. Scrutinizing these topics would be interesting in itself, but it is justified by the policy processes mentioned. In the 2014-2020 time period of EU development policy the development tools organized from lower levels, the communal and integrated regional development all obtain a much larger role than before (CLLD, 2013; ITI, 2014). In the finalization of my study (autumn 2014) a decision has not been made on what kind of development policy tools the Balaton region is going to possess, but expectedly there will be a possibility for the realization of a locally organized division of resources. Undoubtedly, for the successful transaction of community based development programmes the social cohesion between the territorial participants is going to be indispensible.

Lake Balaton, situated in Transdanubia, Hungary, is the largest lake of Central Europe. It has been a tourist attraction since the end of the $19^{\text {th }}$ century and continuous to develop and expand up to this day. Relying on the economic features, the fact started to be contemplated on in the beginning of the $20^{\text {th }}$ century, that the region should have an individual 
administration and self-government to a certain extent. The greatest hindrance appeared to be the fact that its territory is divided among three counties (Zala, Somogy and Veszprém) that form stable administrative borders. The county is a traditional mid-levelof administration in Hungary, which has always possessed a certain amount of self-government throughout history, the amount of which was different from time to time. Thus it would have caused great difficulties to create a new Balaton unit from the territory of the above mentioned counties. Nevertheless, throughout the first part of the $20^{\text {th }}$ century the idea of the self-government of the Balaton region was present (Marton, 2013).

Following the change of regime in 1989/90 these thoughts were re-evoked in the direction of developing a "Balaton region" with self-government. The central government; however, did not or only partly acknowledge these wishes. The manifestation of this was primarily in the fact that following 1996 the region obtained a special development policy status (Lake Balaton Resort Area), with an individual decisive board (Lake Balaton Development Council) and organization. ${ }^{4}$ At the beginning, to the resort area belonged 164 settlements, nowdays after expansions, it is contains 180. (See the map below.) Since 2000 an individual statute regulates the directions of the development in the Balaton region. ${ }^{5}$ The Lake Balaton Resort Area doesn't have a normal NUTS2 status, which (with other problems) caused a lot of difficulties in the development of this territory in the past decade (Agg, 2010; Kabai, 2013).

Due to the below mentioned social connections and economic functions the wishes pointing toward a bottom-up self-government can be measured and established today as well. (Oláh, $2002 ; 2010)$

\footnotetext{
${ }^{4}$ 1996. évi XXI. törvény a területfejlesztésről és a területrendezésről. (Law of Regional Development and Planning)

52000. évi CXII. törvény a Balaton Kiemelt Üdülökörzet Területrendezési Tervének elfogadásáról és a Balatoni Területrendezési Szabályzat megállapításáról (Law of the Lake Balaton Recreational Area Spatial Plan and the adoption of establishing the Lake Regional Planning Policies)
} 
Figure 1 The Lake Balaton Resort Area after the expansion in 2008 with 179 settlements.

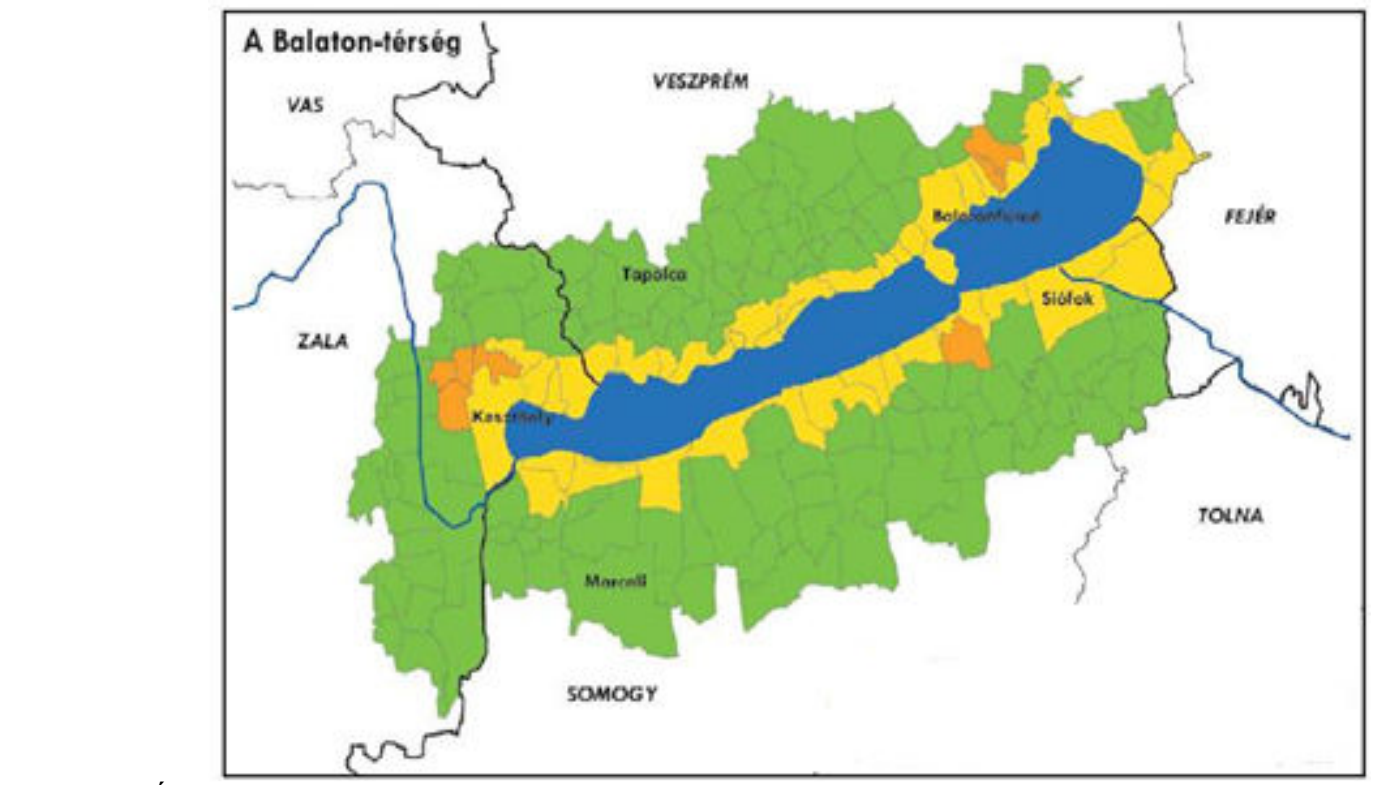

Source: VÁTI-OTH 2010

\section{THEORETICAL FRAMEWORK: REGIONALISM AND COHESION OF SOCIETY}

The spine of the theoretical framework of my study is provided by regionalism or selfgovernance. Both Hungarian and foreign authors agree that the main characteristic of the process of regionalism (as opposed to regionalization initiated from above) is the bottom-up construction. The determination of the top-down and bottom-up processes is what makes its power and governance structure clear from point of view of the construction of the given region (Pálné, 2009). It should be noted, that there is lot of interpretation of political regionalism in Europe (Riedel, n.d.).

Thus regionalismis a bottom-up process, which relies on the coherent system and integration of social, economic and cultural factors (Süli-Zakar, 2003), and which aims at the selfgovernment, independence and minor or major scale of autonomy of the given region in opposition with the central government. Thus regionalism (or regional self-governance) is a political, social and ideological movement, which relies on the ethnic, cultural, lingual, religious and historical features of a given region. (Győri Szabó, 2006)

Based on Süli-Zakar (2005, p. 3) we accept that "Behind the process of regional selfgovernance stands the comparatively permanently prevailing coherent system of natural social - economic - cultural features."

Bourdieu's interpretation (1980) brings us closer to the exploration of the social background of regionalism. The French sociologist identifies regionalism from a social perspective with identity. In his opinion the amount of this identity can manifest in numerous intentions, from 
cultural autonomy to territorial autonomy, until the development of a sovereign territorial unit. Bourdieu connects and explains the concept of regionalism with the category of symbolic or actual (economic) power. Regionalism (in Bourdieu's definition, similar with nationalism.) is only a type of the purely symbolic battles, in which the militants take part in an individual, diffused state or collectively in an organized form, its stake can be symbolic or the perseverance or change of economic advantages and balance of power; in other words the preserving or change of rules affecting the material or symbolic price formation in connection with the development of social identity. Representation in connection with identity is another key concept of Bourdieu's interpretation of identity (Bourdieu 1980).

All of the concepts of regionalism quoted above put the emphasis on social factors, assuming that the sense of community, cohesion and identity in the given community are the main driving forces of the movements for political and social autonomy. In the following I am going to review those theoretical approaches that bring us closer to understanding the cohesion of society.

There is no uniform terminology used among the different disciplines in connection with the cohesion of society. It depends on approaches and the analyzed topics what the users of the term refer to.

Nemes Nagy formulates the roles of the cohesion of society during the development of regions as the following: "For the chance of a strong internal togetherness the economic territorial contract with natural, ethnic-religious similarity, the connection system of a dense settlement network, and the connective force of historical traditions is an important factor." (Nemes Nagy, 2009. p. 186)

The cohesion of society has more sociological and economic approaches. Bruhn (2009) in his theoretical framework says, that there is no universal definition for the cohesion of society, but the conclusion is: for every human group cooperation the criteria is the cohesion. According to an other opinion, because of the universal usage in social sciences, the definition of cohesion become a 'buzzword' (Jenson, 2010).

In the context of regionalism, there is an important interpretation of cohesion. In Larsen's (2010) explanation the definition of cohesion is similar with trust, which is necessary for people to work together as a group: "For modern (or post-modern) societies, the most important aspect is not that citizens believe they share the same religion, family values, attitude towards homosexuality or other ideals; for the everyday operation of highly differentiated societies, the most important aspect of social cohesion is that citizens believe they share the norm of not cheating each other" (Larsen, 2010. p. 5.) 
Regarding to my study, the social cohesion has a strong connection with two other theories. The discussion of the cohesion of society in a territorial dimension cannot be separated from the questions of social capital and territorial or regional identity.

The social capital theories primarily linked to the works of Bourdieu, Coleman and Putnam have several aspects.

Bourdieau (1997) emphasized the community - network aspect of social capital in his works, in which the integral connections are formed. Social capital is capable of creating its own representatives.

Coleman $(1994,1998)$ also interprets the concept of social capital as the relations between individuals. Social capital is a system of relationships that can be utilized and has three basic forms: duties/expectations, information channels and norms/sanctions. According to Coleman power relations and different organizations also form a social capital. According to Putnam(1993; 2000)social capital is the system of relations permeating society. It can be subjected to a strong civilian sector, collective problem solving ability, solidarity and trust. According to him, social capital is a cultural phenomenon, which can be described as a characteristic of large communities and includes a readiness for collective action and public trust.

Fukuyama's thesis $(1995,1999)$ about social capital is similar with Putnam's in the collective interpretation. Fukuyama's view, that the social capital is a kind of a resource, which contains the norms and values which is to facilitate cooperation between people. In this process the focus is on cooperation and mobilization, because social capital is only functional, if it can effect in social relations.

Summarizing: The existence and amount of social capital both have economic, political and social effects and functions. The most important political function of social capital is visible in the expansion and strengthening of civilian society. The existence of social capital is the prerequisite of the creation of a widespread civilian sector which has a role of counterbalancing the central power in apposition with the governmental actions. From a social point of view, the function of social capital is the creation of integration and cohesion. (Orbán - Szántó, 2005)

The question of social cohesion is integrally related to the problems of territorial/regional identity and ties. Identity is an important element of the cohesive force between members of society. On a regional level for a coherent society the sense of togetherness, the territorial ties are essential.The works of Paasi andRaagmaa had a large influence during therecognition of the theoretical system of territorial/regional identityPaasi (1989) interprets the region as a 
social category, which he drafted as a more or less dynamically changing form. Common identity has social, territorial, historical and cultural roots, which can appear in ideas, cultural elements, a peculiar dialect and traditions, as well as a natural and built environment but even in economic success. Paasi (2000) emphasizes the importance of regional importance after examining the region as a socially construed space, which he attributes special importance to, in the institutionalization of regions. In his opinion the building of regions is a process which has four distinct steps:

- Establishment of the territorial structure,

- Formation of common symbols,

- Establishment of regional institutions and connections,

- Evolving of regional identity (Paasi, 2000).

Raagmaa (2002) views territorial identity as the result of a social process, which can equally appear in views, culture, landscapes and economy. In his view identity is an inseparable part of the region concept and an important element of it. Regional identity is simultaneously a conscious and emotional identification and a close link to a territory (region) which can be influenced by historical factors as well.

Palkó (2011) formulates the issue of territorial identity with a synthesizing character, based on mostly the Hungarian results and literature. According to his ascertainment: "Territorial identity can be interpreted as an integral part of the sense of social identity, based on which the individual feels and pleads himself or herself part of a social group that is broader than the personal social network and which is a social group that can be determined based on geographical categories. The legitimacy of local, territorial, public legal and political structures depends largely on the identity of the local society, what is more, it is also the development power and source of the local sense of connectedness, thus the aspect of community cannot be disregarded. Thus regional identity is not simply a social identity type but a form that evolved based on a spatial borders, which includes two interrelated categories that are strongly linked to each other: a geographical - spatial and a cultural; through it the examination of regional development was augmented by a socio-psychological projection."(Palkó, 2011.p. 24)

Summarizing the above it can be stated that the cohesion of society in a territorial/regional dimension is a complex issue, the characteristic (as well as a prerequisite) of which is strong social capital as well as territorial identity and binding To these are all elements (history, culture, landscape, interest, etc.) linked which stimulate the strengthening of community recognized by the individuals. 


\section{MAJOR PROCESSES EFFECTING THE COMPLEXITY OF THE SOCIETY OF LAKE BALATON FROM THE 20TH CENTURY UNTIL TODAY}

Until the end of the $19^{\text {th }}$ century, when modern tourism started, there was little sign of the existence of any kind of common cultural character among the people living on the shore of Lake Balaton. There were even less signs pointing towards a sense of community or any sort of cohesive link between the residents of the northern or southern, perchance the western or eastern basin. At the same time the economic interdependence has early on developed the communal cooperation reaching from one coast to the other.

Until the monograph of Jankó János, appearing in 1902, nobody tried to reveal the cultural and social differences and similarities between the northern and southern coastline of the lake. During his research Jankó drew the conclusion that Lake Balaton much more separates those living on its coast than connects them (Jankó, 1902).

The modern research findings; however, have made the earlier schematic picture much more nuanced. Thus the diversity causing nature of Lake Balaton does not always apply. Looking at the economy of the region, there were strong ties already in the $19^{\text {th }}$ century in the districts of the crossings. In the winter on the ice of the frozen lake, in the summer with other transportation devices the commerce between the -different ecological and economic regions was intensive (Schleicher, 2013).

Despite the economic co-operation several factors have inhibited the establishment of the cohesion of Lake Balaton society. The most determining factor thereof was the difference in the development of the settlements and the region due to economic and social opportunities. Directly on the shore of Lake Balaton the crossings, cultural centres, lordship manors, wine growing settlements, noble villages, peasant communities were simultaneously present in the $19^{\text {th }}$ century as well as the since the $19^{\text {th }}$ century highly determinant and culturally different towns. This often came together with religious and ethnic detachment. (Schleicher, 2013)

The fact that it cannot be talked about a coherent Balaton society until the turn of the $19^{\text {th }}$. 20 th can be derived from this diversity. Intensive economic connections had already developed between the micro-regions of different character, at the same time socio-cultural determinations and the geographically separateness hindered the evolvement of more intensive common co-operations or some kind of integration. All of this was overridden in a few decades by the appearance of tourism and the new life strategies arising from it During the past almost one and a half decade dynamic changes have been under progress within the society of Lake Balaton. The demands and effects of the expanding and rapidly 
developing tourism economy changed the everyday lives of those living in this region and the functions of the regions fundamentally. All of this generated numerous conflicts among the population and eventually resulted in a homogeneous society as far as territorial binding and approach is concerned. It was the economic pressure (tourism) overriding traditional culture that made the local society homogeneous from many aspects and provided the criteria for cohesion.

The most conspicuous changes can be seen in the change of the number of the population. There has been an almost 200\% increase in the population of the Balaton region in 100 years' time (from the beginning of the $20^{\text {th }}$ century to nowdays); the former 100 thousand has risen to 270 thousand until today ${ }^{6}$ (TEIR-KSH Census data) (Figure 2.). This rise in population was largely due to internal migration. The new society of Lake Balaton, overriding the previous one, was born following this largescale change of population, which is fundamentally linked to the touristic character of the region.

Figure 2 The changing of population in LBRA from 1870 to 2011.

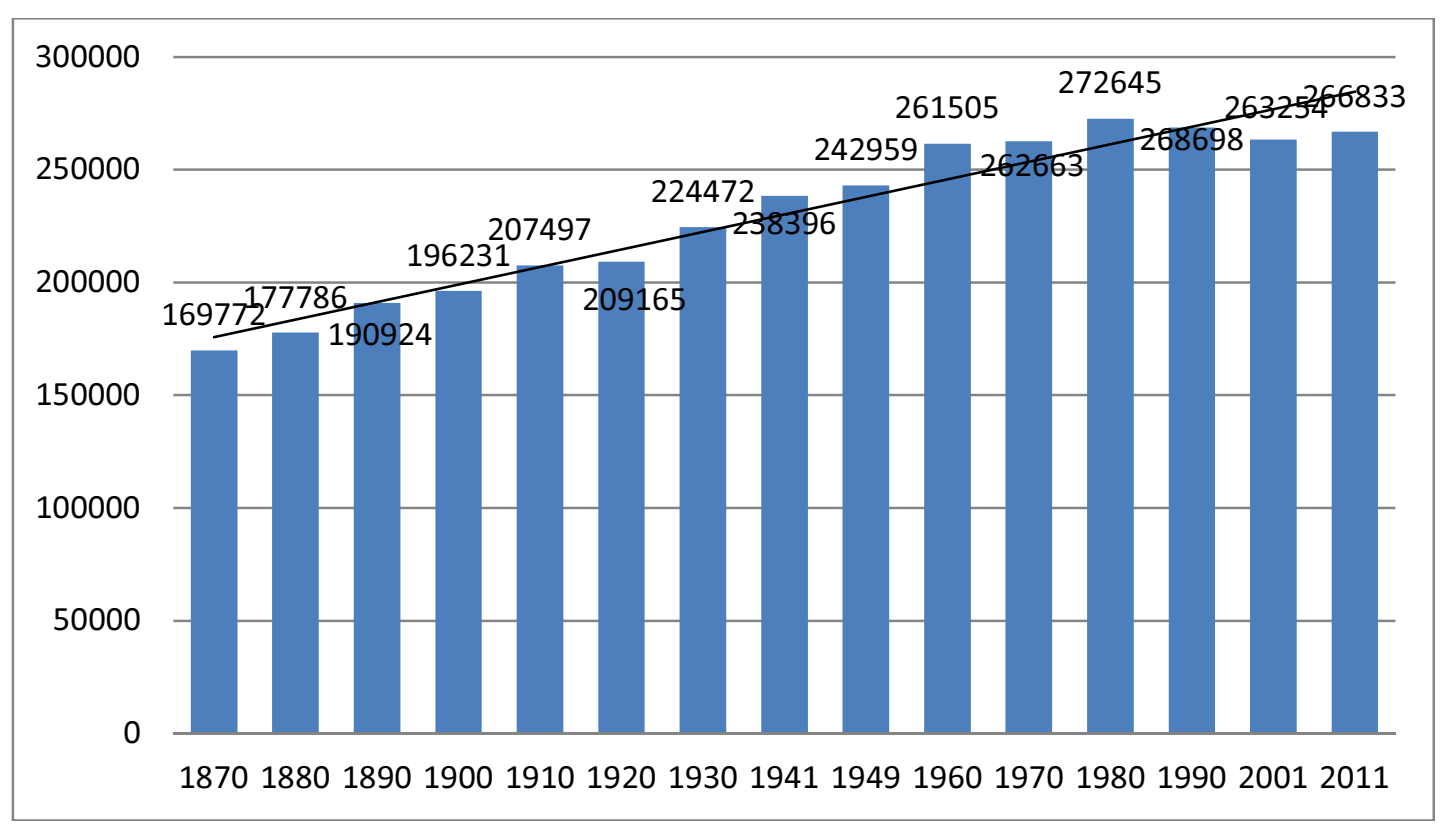

Source: KSH Census Data

We can experience large internal differences in the Balaton region in the background of these processes. Urbanization started at a large scale connected to the popular holiday resorts and the settlements directly on the waterfront. The population of those settlements that are situated on the waterfront increased in the $20^{\text {th }}$ century until 1970 to its double and a half. It is an important fact that $83 \%$ of the population profit of the settlements directly on the waterfront and $98 \%$ of those on the southern coastline in 1960-1970 was due to interior migration.(Pálos,

\footnotetext{
${ }^{6}$ In the 179 municipalities of Lake Balaton Resort Area.
} 
1974) At the same time a significant migration started farther away from the waterfront from the small settlements in the $1950 \mathrm{~s}$, often resulting in a $20-30-40 \%$ decrease in population within one decade. This migration continuous in many instances nowadays as well (Figure 3.).

Figure 3 The population result of migration beetween the census periods int he last 60 years in Balaton Region.

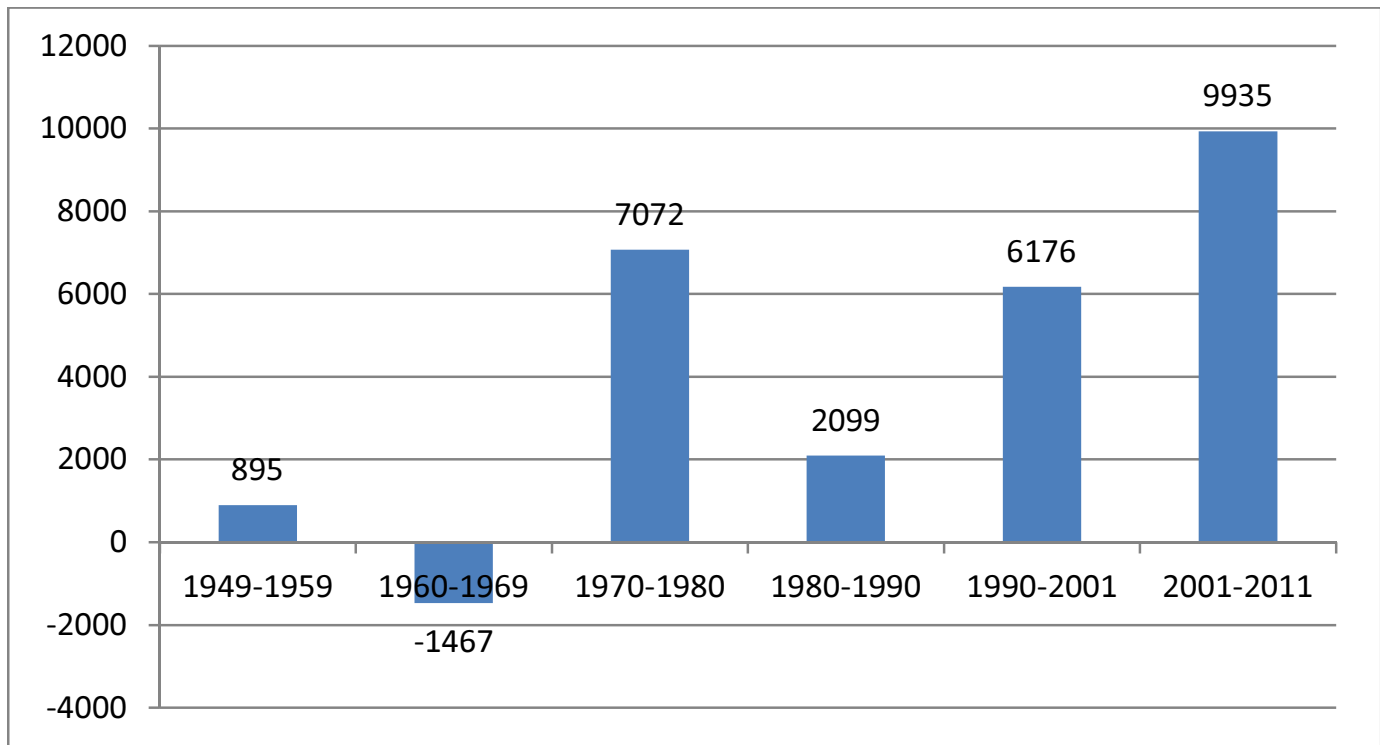

Source: KSH Census Data

The internal migration processes in Hungary have taken up a new direction following 1990. The central region of these interior special movements is Budapest and primarily its agglomeration area. Apart from the capital and its catchment area the target region of internal migration, apart from other urbanized regions, is the region of Lake Balaton. The local population in the last decades, due to a more recent wave of migration, has increased further. At the same time this came together with the large scale migration from the region on the part of young people, thus transforming the age composition of the population in the region. (LBDCA - Situation Analysis 2013)

The wave of intensive settlement in the $20^{\text {th }}$ century resulted in the fact that within the population almost everybody became a new "member" or was born as first or second generation resident of the local society. The regional identity of the residents of the Lake Balaton could only be born in such a dynamic population movement due to the fact that the former cultural values have been preserved only by few people and on the part of the settlers factors were needed to create homogenization.

Apart from domestic migration the society of the region has been influenced by two large scale processes in the past decades. 
After Budapest the surroundings of Lake Balaton are the most popular destination for those foreigners who wish to settle down in Hungary. Most immigrants are German citizens and mostly represent the age group above 50-60. (Kincses, 2009; 2011) Temporary residents belong to the foreign settlers as well. Starting in the 1990s it can be seen that many foreign citizens obtained real estates in the region. According to the findings of studies scrutinizing this topic it can be stated that most of the buyers are citizens of the European Union. Looking at the national borders of the member states almost three fourth of them are German and one seventh is Austrian. Their average period of residence is annually 4,6 months that is longer than that of the domestic holiday home owners. (Kovács et al., 2004)

There is no specific data about the non-Hungarian citizen population who settled or live temporarily by Lake Balaton. The number of real estates owned by foreign citizens can be estimated in a magnitude of tens of thousands and the number of foreigners living here for a longer period of time also exceeds 10 thousand. This can be viewed as a large proportion considering the fact that the permanent population is 275 thousand people.

The local society of the Balaton region is enriched by a high number of domestic holiday home owners. Altogether, an approximately $30 \%$ of the domestic holiday homes can be found in the region. According to the estimations the holiday home owners together with their family members form a stratum of about 166 thousand people. According to the last representative studies they spend in average 3.5 months by Lake Balaton.

Considering all social strata the population of the region is made up of almost 500 thousand people (LBDCA - Situation Analysis 2013).

\section{DISCUSSION: CHARACTERISTICS OF THE COHESION OF THE LOCAL}

\section{SOCIETY}

Following the tendencies above it can be stated that the processes of the past decades have resulted in a complex society, in which all strata (as it will also be visible) have their own binding to Lake Balaton. At the same time, due to their different status, their interests linked to the region are completely different. All of the above provide sources for several social conflicts in this heterogeneous society; however, there are still uniform features, which imply a certain sense of community.

Schleicher's (2010) studies have described most recently the complexity and rootless character of the society of Lake Balaton. The writer pointed out that in the past almost 100 years the local society has been comprised of interest groups with different expectations 
operating along steady lines of division. The most important groups of Lake Balaton society are the following: the "native" residents living here, the newcomers, the holiday home owners spending a few months or even a large part of the year by the lake and tourists spending a few days or weeks.

There are fundamental conflicts between the interest groups, as they all wish to take advantage of different possibilities offered by Lake Balaton. In the past there were (almost continuous) arguments between the communities for the possession of the waterfront territories in connection with animal breeding or the development of beaches. Schleicher described this process as the cultural battle for the carrying of Balaton identity and culture (Schleicher, 2010), which is meanly an anthropological interpretation of these phenomena.

That is true, that these conflicts of the local social interest groups are present nowadays as well and are organized very much along the lines of the problems of the past. For example, in the last years, about the biggest summer festival for youth in Lake Balaton area, there was some debate between the resident settlements and the holiday home owners, or guest. For the first group big festivals are good for the local economy, in the other part, the property owners wants to relax. These have already been discussed in an earlier study (Kabai, 2014).

Otherwise, the social and community changes in this territory can be interpreted as modernization process, in which the new citizenship became the promoter of regionalism.

Despite the observable disintegration in connection with the clashes of interest, the regional binding of the population and interest groups of the region is measurable and definitely traceable already in the past century.

Behind the institutionalization objectives stand as a motivational factor an extraordinarily strong regional binding and identity. According to Oláh's research carried out in the beginning of the 2000s, a regional identity and binding is traceable practically among all social and interest groups of Lake Balaton.

Research has been carried out in 2001-ben in the Lake Balaton Resort Area with the involvement of the leaders of the surrounding settlements, which has supported the fact that the sense of integrity is present on the level of local politics as well. Almost $75 \%$ of those providing an answer have said that the region of Lake Balaton needs an independent selfgovernment, $62 \%$ considered the establishment of a region with licences ideal (Oláh, 2002). Surveys carried out in 2002 have pointed out the fact that according to the common opinion of the local residents at least 10 years have to pass in order for a newcomer to feel himself/herself completely a local resident of Lake Balaton. The everyday duties and affairs 
of the majority of the residents proceeded within the Lake Balaton Resort Area, which implies strong internal interaction (Oláh, 2003).

Later studies have highlighted the fact that the thought of an independent Lake Balaton was supported by a significant part of those questioned; some form of self-government was supported by $82 \%$ of the adult citizens, while a completely independent administration was supported by $81 \%$ of those questioned. The otherwise determining county identity was barely traceable among the local residents, which is overridden by a Lake Balaton identity. Instead of the three development strategic regions concerning the Lake Balaton region, $65 \%$ of those providing answers placed its home town in the otherwisede jure non-existent Balaton region (Oláh, 2007).

In the representative researches carried out in the first half of the $2000 \mathrm{~s} 41 \%$ of the holiday home owners by Lake Balaton considered himself/herself a "Balaton person.” Among those owning a real estate by the lake for a longer period of time, respectively also spent a significant part of the year there, the sense of binding was even larger. Among the domestic social elite a definite binding to Lake Balaton was traceable. (LBDCA 2004; 2006)

All of this can be completed with the fact that among the foreigners living here territorial binding can also be detected. This social group still does not have a widespread lobby power but several organizations have been established in the 2000 s that wished to represent foreigners residing by Lake Balaton. Local media designed specifically for them have appeared along with programs and catering businesses (Kovács et al. 2004).

During the quoted researches it was revealed that geographical surroundings, the specific landscape of Lake Balaton emerge as a significant identity forming power. In the survey carried out in the elite sample group $25 \%$ of those answering named the region as the generating power behind the sense of binding. Based on the inquiries carried out among the domestic citizens the natural surroundings was a decisive factor during their purchase. Similar rates were measurable among the foreign real estate owners. (LBDCA, 2002; 2004; 2006). The character and extensiveness of the civilian sector implies a strong social cohesion and social capital within the region as well. I have referred to the fact above when discussing the theories that the local self-organizing ability originates from the power to advocate local interest in opposition with the central power. In connection with Lake Balaton all of this is linked to the above mentioned fact that generally the actors of regional politics wished to solve the specific problems of the region with bodies controlled from above. The dissatisfaction with the central power and the strengthening in the social power of the region had a motivational effect on the development of a collective identity. 
Already in the beginning of the $20^{\text {th }}$ century the self-organizing ability of the Lake Balaton Society was highly developed. In the years before 1948 approximately 700 non-governmental organizations were operated in the region (4,1/1000 person). It implies the concentration of social activity that in the particular settlement there were often more than 10 organizations. (LBDCA, 2002)

Following the change of regime the civilian sector of the Lake Balaton region was reorganized as well. Compared to the national average index(12.24 organizations/1000 residents) the comparable index of the whole residential area in 2012 was 13.5. In the 52 settlements close to the waterfront 16 in average, in the background settlements 10.2 nongovernmental-organizations fall on 1000 people(the index of Budapest is 21.43.) Thus it is visible that in the Lake Balaton Resort Area the civilian activity and organization exceeds the national average. The differentiation within the region is traceable as well. There are 1.5 times as many non-profit organizations on the waterfront per thousand residents as in the background settlements. Similarly to the national terms the number of registered nongovernmental organizations has been continuously rising in the surroundings of Lake Balaton and the degree of rise is similar as well. While in 2000 there were 2118 non-profit organizations in the region, by 2012 there were already 3701 (KSH-TSAR).

In the territory of the Lake Balaton Resort Area beside the civilian activity of the permanent residents, typically that of the holiday home owners bears a large emphasis as well.

The widespread civilian sector is frequently where tension among the local social interest groups is visible. At the same time only a little more than $5 \%$ of the holiday home owners represent themselves in some kind of non-profit Lake Balaton organization (LBDCA, 2006). The civilian co-operations are mostly made up of the local, permanent residents.

The fact that the tenders handed in by the non-government organizations has gradually risen in the years of the development cycles of 2004-2006 and 2007-2013 shows the strengthening of their activity. In the development period of 2007-2013 in the Lake Balaton Resort Area the non-profit organizations handed in tenders in the third largest scale (LBDCA - Situation Analysis, 2013).

Upon closing this chapter it is worth scrutinizing the issue of the cohesion of Lake Balaton society from the aspect of life quality. In the theoretical chapter it was mentioned that social cohesion primarily appears in a socio-political and life quality dimension on the level of European Union policies. From this aspect many differences can be measured in the Balaton region, more precisely in the Lake Balaton Resort Area. 
One of the appropriate indexes of the comparative study of life quality is the Human Development Index - HDI, which can (restrictedly) be used for the description of differences concerning smaller areas. HDI is the weighted average of three development dimensions (economic performance, life span and educational performance) measured with four index numbers. (Csite - Németh 2007; Garami 2009)

The most recent calculations of 2011 reveal that compared to previous conditions, the statistical sub-regions (LAU1) near Lake Balaton domestically no longer belong to the highest categories, all of their performance number stayed below 0.8, while west of Budapest 0.9 and in several sub-regions of larger towns in Transdanubia (e.g. Veszprém, Székesfehérvár, Győr) results between 0,8-0,9 could be measured. On the whole the Lake Balaton Resort Area still appears among statistical sub-regions with the 30 best Human Development Indexes, but within this category the internal differences have become larger, not in favour of Lake Balaton (LBDCA - Situation Analysis 2013).

A closer scrutiny of the internal situation of Lake Balaton Resort Area makes this picture much more nuanced. There are two statistical sub-regions within the Lake Balaton region that have significantly worse conditions as far as life quality is concerned as the other sub-regions concerning the Lake Balaton Resort Area. The Marcali statistical sub-region (kistérség) still belongs to the micro-regions providing a comparatively acceptable quality of life and in connection with the Lengyeltóti statistical sub-region the measurable results are nationally negatively outstanding. (LBDCA - Situation Analysis, 2013) The difference between the subregions providing a high quality of life such as Balatonfüred, Hévíz, Keszthely and Siófok and the Lengyeltóti sub-region is well illustrated by the fact that it is listed among the 33 most disadvantaged regions to be supported with a complex support program. The Marcali subregion is "only" registered as disadvantaged. ${ }^{7}$

Apart from the above parameters, considering almost all economic and social indexes, significant differences can be measured between the territories on the waterfront and those farther away from the water (Löcsei - Németh 2006).In this aspect of social cohesion significant regional differences can be talked about within the Lake Balaton region, which show the cohesion of the territory units on the waterfront from which the other territories (farther away, disadvantaged) are largely separated.

\footnotetext{
${ }^{7}$ 311/2007. (XI.17.) Government regulation concerning the categorization of beneficiary regions.
} 


\section{CONCLUSION}

Previously I have analysed a few aspects and characteristics of the social cohesion of the society of Lake Balaton, which I have primarily discussed within the framework of the procedure of region establishment. Based on the above, comprehensively the following can be concluded.

As far as cohesion is concerned several dividing lines can be identified in the local society. Partly the disagreements between the different interest groups (residents, holiday makers, owners, etc.), which have been present in the public life of Lake Balaton for more than 100 years. These disagreements often result in conflicts which can bar development or decision making. I have illustrated this with the help of two examples, but from the past decades until today numerous cases could have been highlighted.

Another breakpoint of the cohesion of society within the Balaton region is the field of differences in the life quality. The scale of difference between the waterfront and inland settlements as well as the individual micro region is so large that the cohesion of society from this aspect can by no means be talked about. The territorial detachment of the cohesion of society is further enhanced by the spatial division of the density of non-governmental organizations and the above only mentioned economic aspects. The cohesive factors are significantly more present in a narrow waterfront belt than in the other territories, where these are much weaker.

A sense of Balaton regional identity and belonging is traceable practically among all affected social groups.

In the theoretical part of my study I have touched upon the fact that in case of the cohesion of society we search essentially for the "cohesive force."

According to Oláh's related definition "the geographical environment can be the individual object of identity just as the binding to a certain activity respectively the circumstances that ensure subsistence reaching beyond social and cultural determination." (Oláh, 1998 p. 9)

Broadening the quoted theoretical approach, from the point of the cohesion of society in the Balaton region the natural surroundings, the uniform economic and touristic function and the recognized common interests can be formulated as cohesive power for they all have motivating effects towards the cooperation of the individuals as well as the communities.

This can be complemented with one assumable cohesive power in case of Lake Balaton: the conflict of interest with the central power. One of the driving forces behind the expansive local organizations is the wish to solve the local (regional) issues, for which no resources, 
tools and proposals arrive centrally. All of this is linked to the social and civilian capital concepts discussed within a theoretical framework.

Although the cohesion of society of Lake Balaton is not strong from all aspects, its effect is unquestionable in the events of the past decades pointing towards regionalism. The establishment of administrative regions is not a current issue nowadays, the prioritized character of the Balaton region as far as development policy is concerned is provided. ${ }^{8}$ When planning the developments in the region and in order for their effective execution the above discussed phenomena concerning the cohesion of society is worth taking into consideration.

\section{REFERENCES}

Agg, Z. (1991): Elképzelések egy Balaton körüli megye kialakítására 1919-1989. Comitatus Önkormányzati Szemle I./5-6. 99.

Agg, Z. (2010): How many centres does the Transdanubian region have? Comitatus Önkormányzati Szemle XX./193. 90-102.

Barca, F. (2009). An Agenda for a Reformed Cohesion Policy. A place-based approachto meeting European Union challenges and expectations. Independent Report. Retrieved 05. 26.

010.from: http://www.euterritorialagenda.eu/Related\%20Documents/report_barca_v0605.pdf

Bourdieu, P. (1980).L'identité et la représentation. Élements pour une réflexion critique sur l'idée de région. Actes de la recherche en sciences sociales 35. 63-72.

Bourdieu, P. (1997). Gazdasági tőke, kulturális tőke, társadalmi tőke. In Angelusz R. (Ed.) A társadalmi rétegződés komponensei. (pp. 156-177.) Új Mandátum Könyvkiadó. Budapest.

Bruhn, J.G. (2009): The Group Effect. Social Cohesion and Health Outcomes. Springer.

CLLD (2013).Common Guidance of the European Commission's Directorates-Genreal Agri, Empl, Mare and Regio and Community-Led Local Development in European Structural and Investment Funds. Retrieved 09. 10. 2014. From http://ec.europa.eu/regional_policy/informing/dialog/pdf/clld_guidance_2013_04_29.pd $\mathrm{f}$

Coleman, J. S. (1998). A társadalmi tőke az emberi tőke termelésében. In Lengyel, Gy. Szántó Z.(Ed.).Tőkefajták: A társadalmi és kulturális erőforrások szociológiája. Aula Kiadó. Budapest.

Coleman, J. S. (1994). Társadalmi tőke. In: Lengyel Gy. -Szántó Z. (Ed..).A gazdasági élet szociológiája. Aula Kiadó. Budapest.

Csite, A. - Németh, N. (2007).Az életminőség területi differenciái Magyarországon: a kistérségi szintü HDI becslési lehetőségei. Budapesti Munkagazdaságtani Füzetek. 3.

Fukuyama, Francis (1999): The Great Disruption: Human Nature and the Reconstruction of Social Order. Free Press, New York.

Fukuyama, Francis (1995): Trust: the Social Virtues and the Creation of Prosperity. Free Press, New York.

Garami, K. (2009). A humán erőforrás területi különbségei. Területi Statisztika Vol. 3.

Győri Szabó, R. (2006). Kisebbség, autonómia, regionalizmus. Budapest.

\footnotetext{
${ }^{8}$ Az Országgyúlés 6/2014. (II. 7.) határozata. (Decree of the Hungarian Parliament)
} 
Illés, I. (2009). A területpolitika változási irányai az Európai Unióban MTA RKK-DTI Retrieved 08. 25. 2014. from www.mrtt.hu/konferenciak/teruletfejlesztok/illes.ppt

ITI (2014). Integrated Territorial Investment. Retrieved 09. 10. 2014. from http://ec.europa.eu/regional_policy/sources/docgener/informat/2014/iti_en.pdf

Jankó, J. (1902). A Balatonmelléki lakosság néprajza. Budapest.

Jenson, J. (2010): Defining and Measuring Social Cohesion. Commonwealth Secretariat and United Nations Research Institute for Social Development, London.

Kabai, G. (2014). A balatoni társadalom kohéziójának kérdései. Területi Statisztika. 54./4.

Kabai, G. (2013). A Balaton Kiemelt Üdülőkörzet mozgástere a fejlesztéspolitika rendszerében 2006-2012 között. DETUROPE - THE CENTRAL EUROPEAN JOURNAL OF REGIONAL DEVELOPMENT AND TOURISM. Vol.5 Issue 2.

Kincses, Á. (2009). A Magyarországon élő külföldiek területi elhelyezkedése. Tér és Társadalom XXIII./ 1. 119-131.

Kincses, Á. (2011). A szomszédos országokból Magyarországra történő vándorlások területi vonatkozásai. Területi Statisztika XIV./3. 245-261.

Kovács, E. - Csite, A. - Oláh, M.- Bokor, I. (2004). Sziget a magyar tengeren: külföldi ingatlantulajdonosok a Balatonnál. Szociológiai Szemle 2004./3. 79-106.

KSH - T-STAR Database (Hungarian Central Statistical Office)

Larsen, C. A. (2009): Social cohesion: Definition, measurement and developments.http://www.un.org/esa/socdev/egms/docs/2014/LarsenDevelopmentinsoci alcohesion.pdf (Letöltés ideje: 2016.január 28. 10:58)

LBDCA (2002). A Balaton régió nonprofit szektora. Kutatási zárótanulmány. Balatoni Integrációs Ügynökség Társadalomtudományi Kutatócsoport. (Lake Balaton Development Coordination Ageny Social Science Research Group - The civil sector in Balaton region. Research Report.)

LBDCA (2003). A külföldi állampolgárok ingatlanszerzésének gazdasági és társadalmi hatása a Balaton Kiemelt Üdülőkörzetben. Kutatási zárótanulmány. Balatoni Integrációs Ügynökség Társadalomtudományi Kutatócsoport. (Lake Balaton Development Coordination Ageny Social Science Research Group - Foreign real estate owners in the Lake Balaton region. Research Report.)

LBDCA (2006). A magyarországi elit balatoni kötődései. Kutatási zárótanulmány. Balatoni Integrációs Ügynökség Társadalomtudományi Kutatócsoport. (Lake Balaton Development Coordination Ageny Social Science Research Group - The connections to the Balaton of the Hungarian Elit of Society Research Report.)

LBDCA (2004). Belföldi üdülőingatlan-tulajdonosok a Balaton Kiemelt Üdülökörzetben. Kutatási zárótanulmány. Balatoni Integrációs Ügynökség Társadalomtudományi Kutatócsoport.(Lake Balaton Development Coordination Ageny Social Science Research Group - Hungarian property owners in Lake Balaton Resort Area. Research Report.)

LBDCA (2013) Lake Balaton Resort Area Analysis -A Balaton Kiemelt Üdülökörzet Hosszútávú Területfejlesztési Koncepciója 2014-2020 Helyzetelemzés. Balatoni Integrációs és Fejlesztési Ügynökség (LBCDA) Retrieved 10. 12. 2013. fromhttp://www.balatonregion.hu/a_balaton_regio_201420_tervezesi_feladatai_dokume ntumai

Lőcsei, H. - Németh, N. (2006). A Balaton régió gazdasági ereje. Comitatus - Önkormányzati Szemle XVI./7-8. szám. 7-29.

Marton, I. (2013).A Balaton régió fejlődése - A regionális gondolkodás és a turizmus fejlődésének összefüggései a Balaton térségében. Acta Scientiarum Socialium 39. 161179.

Nemes Nagy, J. (2009). Terek, helyek, régiók. Budapest. 
OECD (2006).The New Rural Paradigm. Policies and Governance. Paris: OECD

Oláh, M. (2007). A megtalált régió. Comitatus - Önkormányzati Szemle. XVII./ 3. 3-18.

Oláh, M. (2002). Az érintettek többségén nem múlik. Vélemények és javaslatok a Balaton régió területi kérdéseiröl. Comitatus - Önkormányzati Szemle. XII./7-8.52-72.

Oláh, M. (2003). Egy rendhagyó régió rendhagyó helyi társadalmáról. Comitatus Önkormányzati Szemle. XIII. 7-8. $42-59$.

Oláh, M. (1998). Közelítési módozatok a regionális identitás térbeliségének megrajzolásához. Comitatus - Önkormányzati Szemle. VIII. / 2. 6-34.

Oláh, M. (2010). The Economic - Social Characteristic of Balaton Region and the Alternatives of its Regional Institutional Development. Comitatus - Önkormányzati Szemle. XX./193. 60-79.

Orbán, A. - Szántó, Z. (2005). Társadalmi tőke. Erdélyi Társadalom III./2. szám. 55-70.

Paasi, A. (1989). A régiók fejlődése és a regionális identitás kialakulása.Tér és Társadalom 3/ 3. $70-79$.

Paasi, A. (2000). Re-constructing regions and regional identity. Retrieved 10. 08. 2014. from http://gpm.ruhosting.nl/avh/Paasi1.pdf

Palkó, K. (2011). Az identitás területi dimenziói a politika tükrében. Doktori értekezés. Pécs.

Pálné Kovács, I. (ed.) (2009). A politika új színtere a régió. Századvég Kiadó. Pécs-Budapest.

Pálos, I.(1974). Népesség, településhálózat, ipar, kereskedelem és mezőgazdaság. In Tóth K. (Ed.). (pp 127-152.) Balaton monográfia. Panoráma Kiadó. Budapest.

Putnam, R. D. (1993).Making Democracy Work: Civic Tradition in Modern Italy. Princeton University Press. Princeton.

Putnam, R. D. (2000).Bowling Alone. The Collapse and revival of American community. Simon\&Schuster. New York.

Raagmaa, G. (2002). Regional identity in Regional Development and Planning. European Planning Studies Vol. 10 1. 55-76.

Riedel, Rafal (non dated). Regionalism in the Context of a Political System. Retrieved 10.10.2014. from drcsummerschool.eu/static/designs/.../getFile.jsp

Schleicher, V.(2013). A Balaton mint kulturális tér. Manuscript.

Schleicher, V. (2010). A Balaton-parti települések identitáskeresése a turizmus szolgálatában. Comitatus - Önkormányzati Szemle XX. /194. 22-35.

Süli-Zakar, I. (2003). A régió: földrajzi integráció. In Süli-Zakar, I. (Ed.): A terület- és településfejlesztés alapjai. (pp. 127-139.) Budapest - Pécs.

Süli-Zakar, I.(2005). Régió, regionalizmus és regionalizáció. In Pusztai, G. (Ed.) Régió és oktatás - Európai dimenziók. (pp. 12-22.) Debrecen.

VÁTI-OTH (2010): Országos terület helyzetkép. NGM-NFM-VÁTI, Budapest. 